\title{
Erratum to: On the Method of Determining Optimal Electricity Consumption from an Electric Traction Network
}

\author{
V. N. Li ${ }^{a, *}$ and N. K. Shurova ${ }^{a}$
}

${ }^{a}$ Far Eastern State Transport University, Khabarovsk, Russia

*e-mail:journal_elektrotechnika@mail.ru

Submitted December 11, 2018; accepted for publication December 11, 2018

DOI: $10.3103 / \mathrm{S} 1068371218110147$

The surname of the second author should read Shurova.

The original article can be found online at https://doi.org/10.3103/S1068371216020127 